\title{
COSMOPOLITAN PERSPECTIVES ON JAPAN'S OFFICIAL DEVELOPMENT ASSISTANCE
}

\author{
Adina Voicila, PhD student \\ National University of Political Studies and Public Administration \\ Bucharest/Romania \\ adina.elena.voicila@gmail.com
}

\begin{abstract}
The Japanese ODA policy transformation ended, or rather began, with the introduction of the Human Security doctrine in its narrative, allowing the Japanese approach to be encompassed within the international development architecture. However, while having as main pillar human security promotion, the Japanese aid structure maintains a strong view to what regards national interest and its importance in the ODA Charter. This has therefore started up worldwide debates on the actual purpose and rationale of the Japanese aid.

This paper presents a different perspective in what regards development assistance policies and Japan is chosen as case study precisely because of the particularities of the Japanese society and Japanese policy. Under the theoretical model proposed by this paper - taking into account human security as reflecting cosmopolitan ideas - I have investigated the Japanese Official Development Assistance policy. The main assumption is that domestic attitudes have paved the way for cosmopolitan approaches in the Japanese aid policy.

Thus, it was observed that altruism, morality and ethics, elements which have already existed inside the Japanese society long before the beginning of coining the ODA policy, have strongly influenced the current ODA practice of Japan; therefore it would be wrong to assume that the human security doctrine, a result of the convergence between domestic forces and international pressures, is used as a tool to hide national self-interests.
\end{abstract}




\section{Keywords}

Cosmopolitanism, Human Security, Japan, Morality, Official Development Assistance policy (ODA)

\section{INTRODUCTION}

1.1. Overview of the problem

Official Development Assistance (ODA) is an important instrument which leads to development. Issues such as decolonization, the Cold War, the oil and economic shocks, environmental concerns, the collapse of dictatorships followed by the democratic wave, the appearance of fragile states and the worldwide (Western) consensus on the Millennium Development Goals (MDGs) and its following processes which have led to the Sustainable Development Goals (SDGs) being discussed and adopted, resulted to a steady evolution of the global aid architecture; each event constructed new policies and agencies which in return reshaped the initial design of aid. The other side of the dynamic international aid architecture encounters the recipients of foreign aid, countries which try to become independent of aid as soon as possible, yet by and large remain unsuccessful.

As detailed below, the current international aid structure is a result of a Western consensus on development, reflected by the Organization for Economic Cooperation and Development (OECD) in general and the Development Assistance Committee (DAC) in particular. The Washington Consensus, embraced by World Bank (WB), the International Monetary Fund (IMF) and the World Trade Organization (WTO) influenced foreign aid through economic reforms and trade-liberalization, with structural adjustment programs, privatization and deregulation becoming a prescription for development and prosperity (Williamson 2004). However, challenges are put forth by the nonWestern development actors, which offer a different approach to development cooperation mostly because they want to share their own development model as an alternative to the mainstream thinking. 
Asia has been the place where solutions were expected to be found, perhaps because many Asian economies had huge economic growths. The changing landscape for the study of development and cooperation should give importance to Asian actors who design their programs quite different from the current donors of foreign aid, based on their own experience and placing emphasis on infrastructure investments, concessional loans, mutual benefits and non-interference in political issues (Kim, Hyun \& Arnold 2010, 141).

Being the third largest economy in the world, with an impressive regional influence, the Japanese "East Asian" miracle became a leading role in helping both East and Southeast Asia develop. The Japanese developmental state put emphasis therefore on economics, in particular trade and investments, in order to foster development, using as specific instruments ODA, Foreign Direct Investments (FDIs), and more recently training and volunteering programs, as well as free trade agreements (FTAs). These tools in particular are part of Japans' foreign policy and reflect the interest of the Japanese state in intervening economically in target countries. Recently, Japan began reshuffling its ODA framework, starting with ensuring transparency of the entire process; moreover, it has slowly reorganised its government- led projects to private sector initiatives, especially for FDIs (Sasuga 2004, 84).

The Japanese development cooperation narrative transformed together with the introduction of the Human Security narrative in the development assistance policy, which allowed the Japanese approach to be encompassed within the international development architecture. However, while having as main pillar human security promotion, the Japanese aid structure maintains a strong view to what regards national interest and its importance in the ODA Charter. This has therefore started up debates on the actual purpose of Japanese aid and its rationale, oftentimes being presented as reflecting national economic interests as mentioned above, therefore deviating from the mainstream-Western norms existent at the international level. 


\subsection{Objectives and Methodology}

In response to an agreed consensus on the Japanese ODA as reflecting pure national economic interests, the main assumption of this paper is that domestic attitudes have paved the way for cosmopolitan approaches in the Japanese aid policy. To briefly detail this, the origin of the Japanese ODA policy results first of all from domestic forces (namely humanitarian ethics prevalent since the Tokugawa period and cultural values existent within the society) that shaped the Japanese aid different from the aid of traditional donors. However, transnational influences have also played their role in adapting and aligning Japan's policy of aid allocation with that of the West. Therefore, the domestic attitudes are represented not only by the government and the bureaucrats who coined the ODA policy but also by the culture, the society and the intrinsic values of humanitarianism deeply entrenched in the culture and society, and they reflect naiatsu (domestic pressure). On the other side, the international aid structure and the Western influences reflect gaiatsu (international pressure), and result in a convergence between the traditional approach to ODA and the mainstream approach of Western donors. However, keeping in touch with the theoretical perspective of the paper, there should be a second convergence within the Japanese ODA policy, between national interest and altruistic, moral value of aid, reflected inside naiatsu, under both honne (real-self) and tatemae (façade).

The paper thus assumes that a human-centred approach which is ingrained in the human security concept is egalitarian, in the sense that it equally treats the security of all individuals belonging to a society. This understanding of human security, which is detailed further in the conclusions of the literature review chapter, could therefore be presented as a cosmopolitan approach, since it assumes that all human beings form a single, moral community, to whom all international actors are responsible.

Therefore, the main question of the paper is what elements of continuity and change from the peculiarity of the Japanese society can be identified in the contemporary practice of Japan's ODA? 
In order to give pertinent answers to the issues raised above, the paper will start by pinpointing the main theoretical concepts - cosmopolitanism and human security - and continue with a brief explanation of the importance of these two chosen concepts in conceptualising the development policy of Japan. Moving on, the paper will assess the elements of continuity and change from inside the Japanese society that influence the development policy and how these are translated into the contemporary practice - more specifically, in the existence of the Japanese International Cooperation Agency.

Furthermore, the present paper is constructed on a qualitative design which can permit drawing up several conclusions that can make way to a more complete paper on this topic which is only briefly approached in this paper. The main research method employed is documentary research. First of all, a historical account of the Japanese ODA system was performed, based on official documents available on-line, such as the White Papers on ODA, the ODA Charters (1992; 2003; 2015), the Mid-term Policies and the Country Assistance Policy, as well as official OECD stats with regard to official flow of aid to recipients. In addition to these, speeches and papers made by government officials were also taken into account in order to understand the human security perspective and the national interest emphasis in dealing with foreign aid. The next step was to review accounts from Asian recipients in what regards the impact of the Japanese ODA policy in the region. This approach was supported by scholarly sources which analyse and understand the impact of Japan's ODA and order to see how the Japanese International Cooperation Agency - JICA understands the human security approach and derive variables for further research.

\section{LITERATURE REVIEW}

\subsection{Cosmopolitanism}

David Held starts his arguments on cosmopolitan thinking referring to the two accounts of cosmopolitanism, which would also represent the starting point of my theoretical approach (Held, Brock \& Brighouse 2005, 11). The term goes back 
to antiquity, as Martha Nussbaum remarks, and defines cosmopolitan as someone whose affinities are "based upon reason rather than patriotism or group sentiment" and is "truly universal rather than communitarian" (Nussbaum, Bohman \& Backmann 1997). This definition has its inspiration in Diogenes's remark of "citizen of the world", in Cicero's "society of humanity" and in Seneca's nation boundaries being found closely to the sun (Fine 2007, 15). However, the first account of cosmopolitanism was set out by the Stoics, who argued that each person lives in both a local community and a wider community of human ideals (Held 2005, 12) 1. In the meaning of the ancient times, cosmopolitanism presented an idea of universality, whereas the modern counterpart choses to readapt the universal community to specific traits of human solidarity, as it will be discussed below. Accordingly, cosmopolitanism reflects the idea of being a citizen of the world. Yet, as a modern thesis, cosmopolitanism moves from the local individual obligations towards moral obligations for those unfamiliar with us.

In light of this idea, the second account of cosmopolitanism has its roots within a key term belonging to the Enlightenment, namely Weltbürger (world citizen). The most important contributions are those found in Immanuel Kant's works, reflecting the idea that nations and "citizens of the earth" who participate in a cosmopolitan society are bearers of the "cosmopolitan right" (Gregor 1996, 353). Cosmopolitanism became an international political order, a moral norm, and a "universal civic society" (Kant 1784, 8). The ultimate purpose of Kant's normative vision is to end wars among states and obtain perpetual peace.

The cosmopolitan regime is a project derived from a humanist-universalist perspective, going beyond local-global divisions. Openness, tolerance and participation are cosmopolitan values, opposing particular, communitarian and exclusivist policies. Following this line of thought, the third account would be the contemporary cosmopolitanism, which, as a theory, has its strong points in the second half of the twentieth century, and for this article, I will focus on two

1 Stoics were the first to refer explicitly to themselves as cosmopolitans -seeking to replace the role of the polis with cosmos, a place where humankind might live together in harmony; 
main approaches - moral and political cosmopolitanism. On one hand, moral cosmopolitans, under the writings of Nussbaum or Scheffler, enforce the idea that there is a moral duty to aid foreigners who are suffering because of poverty and inhuman conditions, as well as a moral duty to respect basic human rights and justice (Nussbaum, Bohman and Lutz-Bachmann 1997, 26). On the other hand, thinkers such as Pogge and Beitz have as source of inspiration Rawls's work on the theory of justice. Yet, their main area of interest is political cosmopolitanism, which focuses on the international level and the creation of an international regulated community. John Rawls's law of peoples and the theory of justice (justice as fairness) are actually considered as being a starting point for contemporary cosmopolitan theories and focuses on the role of states in promoting the cosmopolitan right (Wenar, Martin \& Reidy 2006, 7).

Going back to Thomas Pogge and Charles Beitz, both Rawlsian theorists, they believe that the domestic basic structure presented by Rawls can also be mirrored at an international level and therefore try to offer another perspective over the classical conception of belonging to a human community and the Kantian idea of subjecting all members of sovereign states to the system of rules organized under cosmopolitan right (Beitz 1983 \& Pogge 1994).

To summarise, as Mary Kaldor considers, cosmopolitan vision is both idealist and multilateral in approach, having as source of inspiration Immanuel Kant's perpetual peace (Kaldor 2007, 120). Moreover, the cosmopolitan right enforces the idea that foreigners are to be tolerated and respected in a global community; there is a heavy weight upon everyone when there is an infringement upon rights and values. The cosmopolitan ideal implies a certain arrangement for humanitarian norms, for equality and diversity.

\subsection{Human Security}

Human Security is a relatively new concept and subject of research in both academia and policy circles. The concept, as one might notice, is an outcome of a convergence between security studies and international development (King, Murray 2002). Wolfers has pointed out the two sides of the security concept: 
"Security, in an objective sense, measures the absence of threats to acquired values, in a subjective sense, the absence of fear that such values will be attacked" (Wolfers 1962, 149). In its subjective sense, this means that it ensures protection of an object by decreasing its vulnerability or by eliminating threats to its survival or well-being. However, as it is not the aim of this paper, I will leave aside debates around the traditional conceptualisation of security and the importance of national security.

Human Security, as a concept, developed under two directions. The first one is the Canadian approach - The Human Security Report (2005), where human security is tightly connected to the Responsibility to Protect Principle (R2P), the emphasis being on the security of individuals in front of violence (narrow vision of human security). The International Commissions on Intervention and State Sovereignty (ICISS) concluded that states have a responsibility to protect their citizens from "avoidable catastrophes", and when they fail to do so, it is the responsibility of a "broader community of states" to intervene, in order to prevent humanitarian crises and human rights violations (as specified under the International Commission on Intervention and State Sovereignty; moreover, military intervention is legitimated only and only when ethnic cleansing is involved.

The second approach, which appeared in the Human Development Report, 1994, underlines the importance of development when framing security strategies. It has seven components ${ }^{1}$ which offer a multisectoral, broad approach to the notion of security. The report is a cornerstone publication, because it made human security a distinct notion around the world, and set up the starting point for further enquiries by scholars and policy makers.

At this point, it is essential to explain the results of the literature review. In terms of Japan's official development assistance policy having a cosmopolitan approach in both delivery and implementation, to my knowledge, there is no study in this area. Most of them are focused on the other side of the coin, namely

${ }^{1}$ Economic security, food security, health security, environmental security, personal security, community security and political security. 
national interest and how ODA reflects it. As for Human Security, the same can be stated in what relates its implications on ODA implementation and delivery, although there are many scholars who assess the impact of human security upon East Asia.

An important key implication for this paper is the idea that human security is a common concern and responsibility, in the sense that security of other, no matter their location may affect the security of us. This idea of common responsibility entails that human security addresses all individuals. The importance of human security and its role in development policies contributes to a broader understanding of development. For the sake of argument, human security means ensuring essential conditions for attaining development. It focuses on individuals and communities, while ensuring human development.

Yukiko Nishikawa's book brings forth again the idea that human security is a central part of Southeast Asian states' policy (Nishikawa 2010, 30). She further underlines that by the 1980s, in the area of development assistance, there were worries related to the perception of growth, which led to the evidence that intrastate or domestic conditions give rise to a human-centred approach in development.

The Human Development Report observations can be well applied to Southeast Asia, especially since the dominant discourse of security in the region reflects realist perspectives of self-help and power struggle between states (Nishikawa 2010, 31). The comprehensive security doctrine used in the region only addresses a state's well-being; therefore, territorial integrity was to be ensured by the creation of a strong capable state, whereas security issues were to be solved by using economic development approaches.

Referring to the subject of this paper and addressing the aid conundrum, I argue that all forms of cosmopolitanism presented in this section derive from a concern for morality. My argument is that humanitarian assistance is not a duty to global justice, but represents a moral stance. Richard Miller believes that strong obligations to have concern for other persons derive from a cosmopolitan idea of equal respect, not privileging a particular person over another (Brock, Brighouse 2005, 4). Likewise, Tan also sees the individual as an ultimate unit for moral concern, regardless of his or her nationality and citizenship (Tan 2004, 3). 
Moreover, in connection to cosmopolitanism, Mary Kaldor's perspective on human security has its roots in cosmopolitan thinking, arguing that the security need of individuals and communities, not just states should be addressed; therefore, human security should be incorporated in the security narrative. Kaldor further mentions that security has two approaches, the first one being focused on geopolitics, where security is seen as territorial defence, whereas the second is a cosmopolitan approach, with security being a way of defending individual human beings (Kaldor 200, 78). The latter emphasises therefore human rights, civil society support, economic assistance and regional cooperation, being a bottom-up approach, whereas the former uses diplomatic, economic and military pressures in order to influence other actors. In Kaldor's opinion, the human security doctrine refers to the protection of individuals and communities, challenging the view that security protects only states and borders and combines human rights with human development.

Amartya Sen is also taken into account when explaining the logic behind human security a specific concept, far narrower than human development or human rights (Kaldor 2007, 184). Insecurities should take into account everything that is a risk to human survival, thus human security should be an integral part of human rights, guaranteeing freedom from insecurities. This is the logic explaining how human security can be conceptualised and incorporate minimal requirements of human development and human rights. For economic reasoning, human development should have priority in front of national economies. Therefore, human security has tremendous impact on development policies, with the debate being on economic growth and conditionality versus individual security.

Therefore, I can assume that a human-centred approach which is ingrained in the human security concept is egalitarian, in the sense that it equally treats the security of all individuals belonging to a society. If this idea would be taken to the ODA-level, I would expect that the egalitarian direction of human security results to a sense of common concern, not self-interest. Therefore, the logic would be that through an assistance policy which has as main pillar human security, individuals to whom ODA is addressed have equal moral worth and receive aid because of common concerns. 
This understanding of human security could therefore be presented as a cosmopolitan approach, since it assumes that all human beings form a single, moral community, to whom all international actors are responsible. In particular, moral cosmopolitanism resonates best with the ideas reflected by human security which treats moral claims of individuals equally and sees them as the units of ultimate moral value.

\section{LINKAGES BETWEEN ODA AND HISTORY AND CULTURE}

At the end of the 1970s, Ezra Vogel described Japan as the most dynamic industrial nation worldwide, because of two inseparable and independent variables: a strong economy and a cohesive society (Vogel 1999). Yet, years earlier, Ruth Benedict observed the singularity of the Japanese society, moulded in a way that emphasized not Confucianism or Buddhism, but the Japanese particularity (Benedict 2005, 19). Therefore, being "both aggressive and unaggressive, both militaristic and aesthetic, both insolent and polite, rigid and adaptable, submissive and resentful of being pushed around, loyal and treacherous, brave and timid, conservative and hospitable to new ways" (Benedict 2005, 2), the Japanese national and cultural identity and how the Japanese can be understood became a popular research subject which embraced visions of individuality and uniqueness of the Japanese culture, society, and economy.

In what concerns the ODA policy, overseas assistance became Tokyo's main foreign policy instrument, used as an investment tool, as a solution for the regional animosity, as an expression of economic power and primacy, and as a tool for building confidence and global leadership. All these are features remarked in the OECD Peer Review of Japan, where the traditional donors see the Japanese ODA as mirroring Japan's "long-term interests" ${ }^{1}$. It can be understood therefore that the Japanese ODA system is indispensable for

${ }^{1}$ As seen quoted several times in OECD-DAC Peer Reviews of Japan. 
regaining Japan's national pride and status as well as reflecting both domestic politics and economics. This means that if we are to relate the perceptions of the major stakeholders in the field of development aid with the Japanese distinctive ODA characteristics, it would be safe to assume that Japan is at a crossroads between East and West, not only in political, social, economic or cultural standings, but in the value of its ODA.

\subsection{Understanding society and humanitarianism}

I will start the discussion by referring firstly to the Japanese culture. It is thought that Japan's culture is mainly a culture of shame (Benedict 2005, 222). The history of shame has deep roots within the Samurai era, where shameful acts resulted in suicide (seppuku or hara-kiri). Suicide in itself, in contrast with the Christian thinking, was a noble way of dying instead of a way of bringing shame upon oneself. Therefore, not wanting to make mistakes derives from the high self-esteem of the Japanese people and results in attentive evaluations of others. Consequently, the culture of shame is deeply burned into the Japanese consciousness, and also relates to the shame of surrendering in the Second World War.

Following this argument, the double codes frequently used in the Japanese society can be better understood - honne and tatemae (Naito, Gielen 1992, 161172). Honne is translated as real self, or true to your feelings, whereas tatemae refers to façade and hidden feelings. They are present in all cultural aspects and have affected the credibility of the Japanese society in front of foreigners. Honne is used mainly inside the group, when feeling at home (uchi), whereas when dealing with the outsiders (soto), a façade is preferred. Thus, Japanese are perceived as not truthful by outsiders. However, they do not show real emotions in order not to lead to arguments and conflict, which are harmful to group harmony and bring shame to the one who expresses his honesty.

Maintaining harmony inside the Japanese society relates to the community idea and communal living. As Hofstede defines community as a "society in which people from birth onwards are integrated into strong, cohesive in-groups, which 
throughout people's lifetime continue to protect them in exchange for unquestioning loyalty" (Hofstede 1991, 24), the sense of collectivism which derives from this offers another explanation to the honne - tatemae duality of the Japanese society, besides the shame value. Tatemae reflects words that coincide with group interests, whereas honne relates to a person's own interest, goal or personal wishes (Prasol 2010, 101).

In light of these arguments, I assume that both the shame value and the double coding are present in all aspects of the Japanese society and therefore it is not unusual to presume that they are part of the naiatsu and influence foreign aid allocation. Both Furuoka and Kato see tatemae as altruism, as the moral reasons for allocating aid whereas honne is translated into selfishness, and national interest (Furuoka, Kato 2008). However, their empirical results have shown that Japan allocated more development assistance funds to poorer countries, yet still maintained a close connection and favoured states from Asia which are commercially essential to the Japanese interest.

Therefore, there is a second convergence inside the ODA system of Japan that can explain better how national interest coexist with altruistic motivations. Humanitarianism and humanitarian action are also key terms taken into account when referring to foreign assistance, presumably because both tend to indicate the "humane", altruistic side of aid.

In a non-Western setting, especially in East and Southeast Asia, the Westernderived humanitarian standards and ideals have acted together with the native feelings of humanitarianism ${ }^{1}$. It would be safe to assume that there are variations in the conceptions regarding humanitarianism, because of the existence of different cultures, societal values and political aspirations. But it is not only the differences between societies that result in different attitudes

1 For the Western thinking, humanitarianism mainly revolves around the seven principles identified by Jean Pictet and the International Committee of the Red CrossICRD: humanity, neutrality, impartiality, independence, unity, universality and voluntary service. Thus, humanitarianism represents a humanity attention towards those lacking in needs, and underlines the importance of not getting involved into conflicts, but only providing assistance. 
towards humanitarianism. There can be a difference as noted in the previous arguments within the society, where the official policy discourse underlines certain humanitarian values, whereas the local groups and organisations define themselves as the true representatives entitled of coining humanitarian obligations. The literature on humanitarianism in Asia is however spread among different countries which tend to focus on their own particularities. For example, the Southeast Asian region concentrates on bringing into the discussion on humanitarianism the individual, highlighting the importance of a "human face" for the emergency aid and interventions (ASEAN One Vision 2012). In light of this idea, ASEAN members are "one caring" community, focused on "people-centred" approaches when dealing with foreign aid and humanitarian interventions (ASEAN Charter 2008). Yet, the most important literature on humanitarianism can be found in Japan, where various accounts have been made in order to define and develop humanitarian practices (Checkland 1994, 12). However, all the Asian scholarship focuses on practicality, not on philosophical foundations of humanitarianism.

In the case of Japan, analysing the normative foundations of humanitarianism and their evolutions inside the Japanese society could bring a contribution to the global writings on humanitarianism. The Japanese society has a very strong communitarian ethic. This is translated into loyalty to the state and moral duty to the unfortunate members of a social group. Lehmann assumed that the development of humanitarianism in Japan is due to three interconnected variables, namely Buddhism, Shintoism and Confucianism (Wilson 1983). Isolated from the outside world and the foreign ideas up until the Meiji Restoration (second half of the 1800s) the Japanese culture and society was particularly influenced by the sakoku (national isolation) and shinokosho (four castes) policy, where the Shogunate exerted control over both foreign policy and cultural and social relations (Yeophantong 2014, 3). Here is where special attention should be granted towards the samurai code. As the shinokosho had deep roots within Confucianism, the way of the warriors, namely Bushido, was a moral code of conduct, which derived from Shintoism, Buddhism and Confucianism. The code underlined humanity and bonds as the main features of the same society (Yeophantong 2014, 3-4). Therefore, the samurai, the warrior, 
was the moral individual, expected to act as a guardian for stability and peace (Yeophantong 2014, 3-4). The feudal system in Japan under the Tokugawa dynasty was therefore characterised by humanity, morality and compassion. Indeed, this was reflected into the Bushido code itself and the virtues it entitled. Most of the principles speak of humanitarian feelings. Benevolence is actually considered as the highest attribute of the human spirit, as sympathetic feelings for people, as well as love and pity are the highest characteristics of men (Nitobé 1908).

The beginning of the Meiji period saw a closer interaction with foreign, Western beliefs and ideas, presumably because it was thought that humanitarian ideals imbedded in Western and Christian ethics could be a means towards quick modernisation and integration into the international society (Yeophantong 2014, 10). Fukuzawa Yukichi, considered one of the founders of modern Japan, also underlined the idea that the Japanese ethical principles and the Christian humanitarian values were similar, as the latter actually existed in the Japanese society, but they were viewed and expressed differently (Yukichi 2008).

Therefore, the humanitarian values and principles are more or less uncontested, reflected for example in national opinion polls which show that there is an increasing public support for development assistance, especially in what regards the motivations behind aid. Both international responsibility and humanitarian obligations are the primary motivations supported by the Japanese in polls available online. Those that show support for ODA allocation see Japan as having a moral obligation to help those in need; for example, in 2003, almost $60 \%$ of those interviewed believed that ODA is the main contributor to world peace and reflects moral obligations (Ando 2012).

\section{ANALYSIS OF THE JAPANESE ODA AND THE JICA}

4.1.The ODA policy between national interest and human security

A long-term emphasis on economic growth became the norm in Japanese politics, all throughout the second half of the $20^{\text {th }}$ century. Growth-oriented bureaucrats promoted the usage of ODA as regional economic strategy in the 
Asian region (Leheny, Warren 2010, 6-7). As a result, keizai kyoryoku (economic cooperation) became used in the diplomatic agenda of Japan, in order to engage separately from United States. As noted earlier, Asian developing states wanted to escape from the aid given by U.S. and pursue their own agenda without external guidance.

The Japanese ODA program began in 1954 and the ODA loan program launched four years later. At that time, because of Japan's issues with its balance of payments and export promotion, the ODA loans were intended to promote Japan's exports to developing countries, playing their role in sustaining the developmental state. During the 1960s, Japan started to use ODA as an economic tool, using "tied aid" as a norm, mostly because it lacked military power. The 1970s also characterised the Japanese ODA system as having mostly tied aid, yet pressures from international development norms started to shift aid towards human needs. The negative criticisms brought the Japanese ODA policy to untie all aid by 1980s in theory as in practice aid given through private investors continued to be tied (Hook, Gilson, Hughes \& Dobson 2005, 205).

Because of mercantilist traits of the Japanese economy and their integration within the semantics of ODA policy, research on Japanese aid emphasised most of the time distinctions between the leading donors' policies and the Japanese ones. During the 1980s, the focus of the studies was on how bureaucracies work in the aid structure of Japan, and on the strategic use of foreign aid as an integrated part of the Japanese foreign policy oriented on security ${ }^{1}$. All of the English-Western scholars pointed out to the high percentage of loans, rather than grants, and to the tied aid which promoted Japanese exports. In 1995, David Arase's Buying Power continues the discussion by placing importance on political economy and developmental state. In the end, Arase concludes that Japanese ODA is sensitive to the interests of Japan's firms. Moreover, while foreign assistance brings forth growth, the recipient remains dependent on the economic interests of Japan (Arase 1995, 13). Recent calls have also been made in

1 The most important writings available in English are Alan RIX, Japan's Economic Aid: Policymaking and Politics, Croom Helm, London, 1980 and D.YASUTOMO, The Manner of Giving: Strategic Aid and Japanese Foreign Policy, Lexington Books, Lexington, 1986. 
regard to reconnecting ODA with business interests, as the Japanese business community stresses upon the idea of aid should restructure its priorities in order to ensure the interests of the Japanese state, underlining once again that aid policy objectives are still presumed to be tightly connected with commercial interests (Sunaga 2004, 4).

Yet, there is little to be said about advocates of Japanese ODA policies after the integration of a human needs approach in the rhetoric of aid allocation. Moreover, Japan sought to contribute to the crafting of World Bank's 1993 Report, but the idea of the "East Asian model of development" clashed with the mainstream consensus and was not promoted worldwide (World Bank 1993, 6). As explained in the theoretical part of the paper, human security discourse gained popularity, by focusing on individual human beings rather than the traditional understanding of security. For Japan, adapting this model to its framework of aid allocation was quite appealing. Human Security, as coined by UNDP, fits Japan's two major characteristics of foreign aid allocation - focus on economic growth and developmental state. Moreover, it provided a justification on the lack of military operations of the Self-Defence Forces.

In what regards aid allocation and amount, as seen by analysing official reports, Japan increased its ODA and became the number one donor in the world until the Asian Economic Crisis in 1997. The success of the Japanese developmental model as mentioned in the introduction was even recognised by the international community (as seen in various World Bank reports). Therefore, the ODA policy continued to change according to the global trend. The most important motivation behind such an abrupt shift, taking into account that Japan's stance was to ensure economic growth would be the development of the human security concept (Japan's ODA White Paper 2016).

The Japanese development model is rooted in history and motivation outlined in the preceding section. Yet, the key features are discussed below. Interestingly though, the model, even if it adapted to the international development arena and suffered changes in policy priority and aid modalities, never lost inconsistency and remained sturdy compared to other major donors. The Japanese ODA policy is based on the non-intervention principle, grounded in the idea of self-help, as seen in Japan's Official Development Assistance White 
Paper 2006-2016. Self-help was instrumental during the economic recovery and development of Japan. Therefore, the principle was to be reflected into the aid policy as well, emphasising the idea that states request aid and have ownership over the aid disbursed. Thus, the Japanese aid has fewer conditions imposed on aid disbursements than the aid allocated by major donors (Lancaster, Leheny \& Warren 2010, 29). In light of this argument, non-interference is also an ingrained principle, pre-dating Meiji era, and relates to the idea that it is best not to entangle, not because of a lack in initiative but because the one which receives your help ends up owing you, having an obligation which is limitless in essence (Benedict 2005, 111). Therefore, it can be seen that in the ODA practice, the principle of non-interference and self-help is equal to the idea that recipient does not need to shoulder a debt of gratitude to Japan, but needs to have initiative and act. To support this argument, Arase believes that the principle of self-help leads to recipient states taking pride in their development achievements (Arase $2005,11)$.

However, the historically strong loan prioritization of the Japanese ODA has been subject to international concerns, because it might result in debts for recipients, especially poor states (OECD 2010). Yet, it should be noted following the recent OECD report that Japan follows a trend of increased technical cooperation via grants and decreased loan usage in ODA disbursement (OECD 2017).

In what regards grants, technical cooperation is mainly prioritized to human development and capacity development (JICA Report 2017). Dispatching experts and trainees is therefore the main mechanism through which JICA ensures that developing countries have their own personnel trained. Such bottom-up pattern of assistance raised once again the importance of strengthening individuals, communities and connecting them with the governments and local authorities. To further emphasise the role of people empowerment and human security, the Japanese government has also implemented a financial assistance program for development projects since 1989, the "Grant Assistance for Grassroots Projects (GCP)", supporting various non-governmental organizations (NGOs), as well as local authorities. This scheme supports grassroots level reforms and financial assistance is granted to 
small-scale projects which focus on human security and socio-economic development.

Japan has also relied on the ODA policy in order to boost its power and influence within the international arena. Trinidad also supports this idea, as well as Arase and the ODA Charter itself, underlining the ODA as an international diplomatic tool to advance the Japanese political interests. In the Charter, ODA is also mentioned as an instrument for keeping friendly relations with the neighbour states and smoothing tensions in the region. Moreover, human security coined as a pillar of development assistance is envisioned by Trinidad as a central idea for peace building (Trinidad 2007, 95).

\subsection{The Japanese International Cooperation Agency (JICA) and Human Security}

Human security is for Japan an important pillar for its foreign policy as well as society, as it addresses first and foremost needs and moral obligations which arise from insecurities faced by individuals. The importance of such a concept has not only been emphasised by academics and practitioners, but also by the Japanese ODA system, in particular JICA -Japan International Cooperation Agency. Yet, there has been little attention given to this, even if Japan is the only government fully committed to promote using ODA human security (Kamidohzono, Gomez \& Mine 2015, 2).

Both freedoms from fear and from want resonate with the Preamble of the Japanese Constitution (Kamidohzono 2015, 14), whereas freedom to live in dignity is tightly connected with Japanese moral obligations to help protect others. Yet, the Japanese government became involved with the human security doctrine by founding the United Nations Trust Fund for Human Security (UNTFHS) in 1999 and later on incorporating the idea of human security as a basic principle in the ODA Charter of 2003. For JICA however, human security gained importance in the same year, under Sadako Ogata, former JICA President, who is worth mentioning for its important role in organizing an administrative and organizational reform to expand the autonomy of JICA as an implementation agency. In the end, human security became one of the pillars for 
the internal reform, emphasising focus on people, top-down protection and bottom-up empowerment (Kamidohzono 2015, 6).

The first pillar of internal reform focused on encouraging field-oriented activities to overseas offices, which was translated into transfer of both human and financial assets to recipient countries. The second pillar stressed upon effectiveness and interconnectivity between development and humanitarian aid, underlining the importance of one agency to coordinate and implement aid policies, independent from the bureaucracy and ministries. The last pillar human security- focuses more on human security applied on the field, and from here onwards, the seven perspectives on human security were elaborated, later becoming four approaches of implementing swiftly and effectively aid programs focused on human security.

The reform also allowed a formalization of people-centred approaches, in response to the already discussed critiques related to Japanese aid. In light of this idea, by analysing the official policy paper on human security (JICA: Human Security Report 2007), the specific measures used by the agency to implement ODA are revealed. On a whole, human security is based on protection (of the vulnerable) and on empowerment. On a practical level, human security is focused on five basic principles: targeting comprehensively both freedom from fear (fear from conflicts, natural disasters, economic crises, diseases, terrorism) and want (poverty); cooperation in order to address socially vulnerable human beings; empowerment through offering government support and capacity for local communities; cooperation for addressing global risks via international partnerships; and conflict-prevention and risk management via monitoring and facilitating transition from one stage of development to another(JICA: Human Security Report 2007, 2-3).

Moving onwards, there are four main areas linked with the Japanese and JICA human security approach: natural disasters, climate change, infectious diseases and violent conflict. By analysing the data available in the official reports ${ }^{1}$, it is

${ }^{1}$ As well as the Kyoto Protocol to the United Nations Framework Convention on Climate Change (UNFCCC); the Environmental Conservation Initiative for Sustainable Development (Eco-ISD) ,2002; The Climate Finance Impact Tool (JICA Climate-FIT). 
worth noticing that the idea of global human security existed in the ODA narrative all throughout the 1990s. The Japanese term, jinrui no anzen hosho, is translated as "the security of the whole of humanity", and reflect even further cosmopolitan values in the ODA approach of Japan - affirmation supported by Japan at the ODA Denver meeting, under "Initiatives for Sustainable Development (ISD) toward the $21^{\text {st }}$ century".

\section{Table 1}

Approaches on development assistance in order to achieve human security

\begin{tabular}{|c|c|c|}
\hline $\begin{array}{l}\text { ODA Mid-Term Policy } \\
\text { (MOFA, 2005) }\end{array}$ & \multicolumn{2}{|c|}{$\begin{array}{l}\text { Four Perspectives and Four Approaches } \\
\text { (JICA, 2004-2015) }\end{array}$} \\
\hline & Perspectives & Approaches \\
\hline $\begin{array}{l}\text { Focusing on people and } \\
\text { their needs }\end{array}$ & $\begin{array}{l}\text { Focusing on people and } \\
\text { their needs }\end{array}$ & \\
\hline $\begin{array}{l}\text { Strengthening individuals } \\
\text { and } \\
\text { communities in addition to } \\
\text { governments }\end{array}$ & \multirow[t]{2}{*}{$\begin{array}{l}\text { Realizing both protection } \\
\text { and empowerment }\end{array}$} & $\begin{array}{l}\text { Combining } \\
\text { top-down } \\
\text { and } \\
\text { bottom-up } \\
\text { approaches }\end{array}$ \\
\hline $\begin{array}{l}\text { Empowering people as an } \\
\text { agency for } \\
\text { development rather than } \\
\text { recipients of } \\
\text { aid }\end{array}$ & & \\
\hline $\begin{array}{l}\text { Focusing on the people in } \\
\text { crisis and } \\
\text { the potentially vulnerable }\end{array}$ & $\begin{array}{c}\text { Focusing on the socially } \\
\text { vulnerable and those under } \\
\text { crises }\end{array}$ & \\
\hline Providing cross-sectoral aid & & $\begin{array}{l}\text { Providing } \\
\text { cross- } \\
\text { sectoral aid }\end{array}$ \\
\hline $\begin{array}{l}\text { Respecting cultural } \\
\text { diversity and }\end{array}$ & & \\
\hline
\end{tabular}




\begin{tabular}{|l|l|c|}
\hline human rights & & \\
\hline & Tackling both 'fear' and 'want' & \\
\hline & & $\begin{array}{c}\text { Partnership } \\
\text { with } \\
\text { various } \\
\text { actors }\end{array}$ \\
\hline & & Managing \\
& Responding to cross-border & downside \\
& threats & risks \\
\hline
\end{tabular}

Source: KAMIDOHZONO, "Embracing Human Security...", p.8

\section{CONCLUSIONS}

In this paper, I tried to approach a different perspective in what regards development assistance policies, and I have chosen Japan precisely because of the particularities of the Japanese society and Japanese policy. As discussed in the paper, Japanese ODA paper has as main pillar human security, yet it still emphasises the role of national interest in pursuing development assistance; this idea is also highlighted by numerous writings and theoreticians who stress upon the idea that Japan should move towards the Western approach of disbursing foreign aid, having a more altruistic, moral attitude towards development assistance.

Therefore, the main argument of this paper is that the principle of helping those in need focused the Japanese ODA practice more on the needs of individuals, moving development assistance away from selfish motivations or interests. Yet, in order to infirm or approve this affirmation, observations had to be made not only the policy itself, but also on the domestic attitudes which influenced the coining of Japan's aspirations in foreign aid allocation. Consequently, I took into account the assumption that domestic attitudes have paved the way for cosmopolitan approaches in the Japanese aid policy. 
Hence, what are the elements of continuity and change derived from the Japanese society that can be identified in the contemporary narrative of Japan's ODA policy? Yoichiro Murakami claims that societies change because of various reasons, most of them being related to the existence of threats. What happened in Japan after the Second World War was in her vision, a radical change in the nomos that governed the society, by bringing new, imported nomos from the Western societies (Murakami, Kawamura and Chiba 2011, 31). However, I argue that the duality present at the level of society and at the level of the development assistance policy reflects the idea that the nomos inherent in the pre-war Japanese society is still part of the current "imported" nomos, because, in order to survive, self-constructing your own nomos is fundamental to all societies. Therefore, the humanitarian ethics, legacy from the pre-Tokugawa period, the Bushido code, the duality of the Japanese individual in expressing both honne and tatemae are inherent for the development assistance policy of Japan, and they not necessarily clash with the mainstream thinking, but coexist harmoniously. Both practices of honne and tatemae in aid policy can be understood on one hand as a method through which the Japanese ODA program can include the universal values and humanitarian, altruistic considerations promoted by traditional aid donors. Yet, as proven throughout this paper, altruism, morality and ethics already existed inside the Japanese society long before the coining of the Japanese ODA policy; therefore it would be wrong to assume that the human security doctrine, a result of the convergence between naiatsu and gaiatsu, is used as a tool to hide national selfinterests.

At this stage, the main assumption of the paper cannot be fully testified because the Japanese context entails peculiarities in which dualities exist and interact in all aspects of society, politics and economy. Moreover, it would not be wise to base the research validity on humanitarian grounding, as humanitarianism is a shifting moral terrain and provides no stability when coining a policy. Nevertheless, I would also like to raise an important last argument in defence of my paper. As analysed previously, I can derive the idea that humanitarianism allows a shift in discourse and raises interesting debates not only among international actors in development but also inside the society itself. For Japan, 
there is not only the societal values which are more or less ignored when analysing the motivations behind allocating aid; the past, marked by conflict and losses still has a powerful hold over popular opinion, especially in the East Asian region. This might shed light upon the way in which the Japanese ODA was misunderstood as reflecting personal interests, nationalistic agendas or communitarian values.

Moreover, humanitarianism does not necessarily promote or encompass cosmopolitan values and rights, but can become the cornerstone for a cosmopolitan complexion of an ODA policy, because, as Mary Kaldor underlines, building peace goes hand in hand with achieving a cosmopolitan culture, based on inclusion, tolerance, democracy, empowerment and multiculturalism (Kaldor 2007, 114). Furthermore, Kant also assumed that the cosmopolitan right can allow cultures to refuse interactions and promote isolation, praising both Japan and China in following wisely and prudently isolationist policies (Kant 2007, 23). Their actions had therefore moral ends, creating inside the states what Kaldor names "islands of civility", spaces in which communities interact and do not depend upon foreign knowledge.

To conclude, the idea mentioned in the first pages of the Japanese Constitution, "that laws of political morality are universal and that obedience to such laws is incumbent upon all nations", reflects not only the gaiatsu, namely the international pressure, but also the naiatsu, meaning the domestic values of the Japanese society. In defending this argument and mirroring it inside the ODA policy, further evidence is needed in order to support this affirmation, which is why the paper re-opens up further discussions on the true motivations behind foreign aid allocation, by analysing in-depth ODA projects and their applicability on the field. 


\section{REFERENCES}

- Ando, Naoki.2012. "Prospect of Development Assistance: Japan's Opinion Poll and Burden Sharing", GRIPS, No.11-30, http://www.grips.ac.jp/rcenter/wp-content/uploads/11-30.pdf.

- Arase, David. 2005. Japan's Foreign Aid: Old Continuities and New Directions, London: Taylor \& Francis.

- Barnett, Michael, and Weiss, Thomas G.. 2008. "Humanitarianism: A Brief History Of The Present", in Michael Barnett, Thomas G.Weiss, Humanitarianism In Question: Politics, Power, Ethics, New York: Cornell University Press;

- Beeson, Marc. 2014. Regionalism and Globalization in East Asia: Politics, Security and Economic Development, New York: Palgrave MacMillan.

- Beitz, Charles. 1983. "Cosmopolitan Ideas and National Sentiment." Journal of Philosophy 80, no. 10: 591-600;

- Benedict, Ruth. 2005. The Chrysanthemum and the Sword: Patterns of Japanese Culture Cleveland: Meridian Books.

- Brock, Gillian and Harry Brighouse (eds.).2005. The Political Philosophy of Cosmopolitanism, Cambridge: Cambridge University Press.

- Buzan, Barry. 1991.“New Patterns of Global Security in the 21th Century", International Affairs, 67, 3: 431-451;

- Buzan, Barry. 1991. People, States and Fear: An Agenda for International Security Studies in the Post-Cold War Era, 2nd ed., New York: Harvester Wheatsheaf.

- Clinton, David. 1994. The Two Faces of National Interest, Louisiana: Louisiana State University Press.

- Delanty, Gerard. 2012. Routledge International Handbook of Cosmopolitan Studies, London: Routledge.

- Dennett, Tyler. 1934.Review of The Idea of National Interest: An Analytical Study in American Foreign Policy by Charles A. Beard in The American Historical Review, 39, No. 4, Jul: 742-744;

- Eccleston, Bernard.1989. State and Society in Postwar Japan, South Hampton: Polity Press. 
- Furuoka, Fumitaka and Iwao KATO. 2008. “The 'Honne - Tatemae' dimension in Japan's foreign aid policy: Overseas Development Aid allocation in Southeast Asia", Electronic Journal of Contemporary Japanese Studies, No.6, http://www.japanesestudies.org.uk/articles/2008/FuruokaKato.htm.

- Gregor, Mary J. 1996. (ed.). Kant. The Metaphysics of Morals, Cambridge University Press.

- Hook, Glenn D., Julie Gilson, Christopher W. Hughes, and Hugo Dobson. 2005. Japan's International Relations: Politics, economics and security, London: Routledge.

- Hudson, Alan and Linnea Jonsson. 2009. 'Beyond Aid' for Sustainable Development, ODI Project Briefing ODI, London.

- Hyun, Oh-Seok and David Arnold (eds.). 2010. Emerging Asian Approaches to Development Cooperation. Seoul: Korea Development Institute-The Asia Foundation.

- International Commission on Intervention and State Sovereignty. 2001. The responsibility to protect, International Development Resource Centre, Ottawa.

- Japan's

ODA

Charter. http://www.mofa.go.jp/policy/oda/page_000138.html

- Japan's Official Development Assistance White Paper 2017. Japan Ministry of Foreign Affairs, (MOFA).

- JICA.2017. JICA 2017 Annual Report, JICA, Tokyo, https://www.jica.go.jp/english/publications/reports/annual/2017/index.h tml.

- Kaldor, Mary. 2007. New and Old Wars: Organized Violence in a Global Era. Stanford University Press.

- Kaldor, Mary. 2007. Human Security. Polity. Cambridge. 1 edition.

- Kamidohzono, Sachiko G., Oscar A. Gomez and Yoichi Mine. 2015. "Embracing Human Security: New Directions of Japan's ODA for the 21st Century". JICA-RI Working Paper. No.94. March.JICA Research Institute.

- Kant, Immanuel. 1784. "Idea for a Universal History with a Cosmopolitan Intent".

Gothaische

Gelehrte

Zeitung. 
https://www.marxists.org/reference/subject/ethics/kant/universalhistory.htm.

- Kant, Immanuel. 2007. Perpetual Peace. London: FQ Classics.

- King, Garry, Christopher Murray. "Rethinking Human Security", Political Science Quarterly, 116: 585-9;

- Krasner, Stephen D. 1978. Defending the National Interest: Raw Materials Investments and U.S. Foreign Policy, Princeton.

- Lancaster, Carol. 2010. "Japan's ODA: naiatsu and gaiatsu. Domestic sources and transnational influences". In D. Leheny and K. Warren, (eds.), Japanese Aid and the construction of Global Development, Abingdon: Routledge.

- Morgenthau, Hans J. 1952. "Another 'Great Debate': The National Interest of the United States," American Political Science Review, 46, 4: 961-962.

- Morgenthau, Hans J. 1951. In Defense of the National Interest: A Critical Examination of American Foreign Policy, University Press America.

- Morgenthau, Hans J. 1948. Politics Among Nations: The Struggle for Power and Peace. New York: Alfred A. Knopf.

- Morgenthau, Hans J. 1962. The Decline of Democratic Politics (Politics in the Twentieth Century), Chicago University Press.

- Murakami, Yōichirō. 2011. "On Tolerance”. In Noriko Kawamura, Yōichirō Murakami and Shin Chiba (eds.), Building New Pathways to Peace, Seattle: University of Washington Press.

- Naito, T. and U. Gielen. 1992. "Tatemae and Honne: A Study of moral relativism in Japanese culture". In U. Gielen, P. Uwe, Leonore Loeb Adler and Noach Milgram (eds.), Psychology in international perspective, Amsterdam: Swets and Zeitlinger.

- Nakanishi, Hiroshi. 2003. "Military Power in International Politics: Can the Beast be Tamed?", Gaiko Forum 3, 3, Fall: 3-12.

- Nishikawa, Yukiko. 2010. Human Security in Southeast Asia. London: Routledge.

- Nitobé, Inazo. 1908. Bushido- The Soul Of Japan, 13th Edition. http://www.gutenberg.org/files/12096/12096-h/12096-h.htm. 
- Nussbaum, Martha. 1997. "Kant and Cosmopolitanism”. In J. Bohman and M.Lutz-Bachmann (eds.), Perpetual Peace: essays on Kant's cosmopolitan ideal. London: The MIT Press.

- ODA Mid-term Policy. 1999. Ministry of Foreign Affairs, Tokyo, http://www.mofa.go.jp/mofaj/gaiko/oda/seisaku/chuuki/sei_1_4.html.

- OECD. Development Co-operation Report 2017 OECD Publishing, Paris.

- OECD.2010. OECD Fact book 2010: Economic, Environmental and Social Statistics, OECD Publishing, Paris.

- OECD: Development Aid at a Glance. 2017. Statistics by region. OECD.

- OECD-DAC.2010. Peer Review of Japan. Development Assistance Committee-OECD. Paris.

- Paris, Roland. "Human security: paradigm shift or hot air?" 2001. International Security 26. 2: 87-102.

- Pictet, Jean. 1979. The Fundamental Principles of the Red Cross, Geneva: Henry Dunant Institute.

- Pogge, Thomas.2002. World Poverty and Human Rights. Cambridge: Polity Press.

- Pogge, Thomas. 1994. "An Egalitarian Law of Peoples." Philosophy and Public Affairs.23, 3: 193-224.

- Prasol, Aleksandr Fedorovich. 2010. Modern Japan: Origins of the Mind: Japanese Tradition and Approaches to Contemporary Life, Singapore: Stallion Press.

- Rawls, John. 1999. A Theory of Justice. Cambridge: Harvard University Press.

- Reiss, Hans. (ed.). 2007. Kant. Political Writings, Cambridge: Cambridge University Press.

- Report: "Human Security and JICA". 2007. http://www.jica.go.jp/english/publications/jica_archive/brochures/pdf/h uman.pdf

- Sasuga, Katsuhiro. 2004. Microregionalism and Governance in East Asia. London: Routledge.

- Scheffler, Samuel. 2009. "Conceptions of Cosmopolitanism". Utilitas 11: 255276. 
- Sunaga, Kazuo. 2004. “The Reshaping of Japan's Official Development Assistance (ODA) Charter", FASID Discussion Paper on Development Assistance, 3, Nov, 4.

- Tan, Kok-Chor. 2004. Justice Without Borders: Cosmopolitanism, Nationalism, and Patriotism, Cambridge University Press.

- The Human Development Report. 1994. New York: Oxford University Press. http://hdr.undp.org/en/reports/global/hdr1994/chapters/.

- The Human Security Report 2005: War and Peace in the 21st Century. 2005. http://www.hsrgroup.org/human-security-reports/2005/overview.aspx.

- Trinidad, D. 2007. "Japan's ODA at the Crossroads: Disbursement Patters of Japan's Development Assistance to Southeast Asia", Asian Perspective 31, 2: 95-125.

- Vogel, Ezra. 1999. Japan as Number One: Lessons for America, Harvard: iUniverse.

- Welch, David A. 2000. "Morality and the 'National Interest'". In Andrew VALLS, (ed.) Ethics in International Affairs: Theories and Cases. Oxford: Rowman \& Littlefield Publishers.

- Wenar, Leif. 2006. "Why Rawls is Not a Cosmopolitan Egalitarian". In R. Martin and D. Reidy (Eds.), Rawls's Law of Peoples: A Realistic Utopia?, Blackwell.

- Williamson, John. 2004. "The Washington Consensus as Policy Prescription for Development". Lecture in "Practitioners of Development" - World Bank, Institute for International Economics. https://www.piie.com/publications/papers/williamson0204.pdf.

- Wilson, George Macklin. 1983-1984. Review of The Roots of Modern Japan. by Jean-Pierre LEHMANN in Pacific Affairs, Vol. 56, 4: 744-746.

- Wolfers, Alfred. 1962. "National Security as an Ambiguous Symbol". In A. Wolfers, Discord and Collaboration: Essays on International Politics. Baltimore: John Hopkins University Press.

- World Bank Report. 2015. "East Asia Pacific Update. Adjusting to a Changing World": http://www.worldbank.org/en/region/eap/publication/east-asiapacific-economic-update. 
- Yeophantong, Pichamon.2014. "Understanding Humanitarian Action in East and Southeast Asia: A Historical Perspective". Humanitarian Policy Group Working Paper. London: Overseas Development Institute.

- Yukichi, Fukuzawa. 2008. An Outline of a Theory of Civilization, trans. David A. Dilworth, G. Cameron Hurst, Tokyo: Keio University Press. 